\title{
Budget cuts force Sweden to consider CERN pull-out
}

[MUNICH] Sweden's particle physicists are trying to persuade their government not to withdraw from the European Laboratory for Particle Physics (CERN) in Geneva, Switzerland, to make savings in Sweden's 1998 research budget.

Withdrawal from CERN is one of the options being considered by a special commission set up earlier this year by the Swedish ministry of education, which is responsible for spending on science, to study ways of cutting SKr150 million (US\$19.5 million) from its budget for large-scale international research collaborations.

The cuts are being made as part of efforts to bring the Swedish economy in line with the so-called 'Maastricht criteria' that will make the country eligible to join a full European economic and monetary union.

Last autumn, Carl Tham, the education and research minister, announced cuts averaging 15 per cent to the budgets of Sweden's national research councils in 1997, in a move intended to save about $\mathrm{SKr} 300$ million a year. Tham said that Sweden's subscription to large international research programmes should bear the burden of further cuts of SKr150 million expected for 1998, and that collaborations with international laboratories - such as the European Molecular Biology Laboratory in Heidelberg — should be closely scrutinized.

Tham appointed Susanne Eberstein, a member of the Swedish parliament with expertise in research policy, to carry out this task. Her report is due to be published at the end of this month.
Drawing on advice from research funding agencies and others, Eberstein has identified complete withdrawal from CERN as a possible way of achieving the planned cuts. She says it is not possible to spread the reductions among different international laboratories, as subscriptions are determined by the gross national product of member states.

This solution also has a financial tidiness because Sweden's annual subscription to CERN - which at SFr27 million (US\$18.5 million) comes to 3 per cent of the laboratory's total budget - is approximately the size of the planned cut.

As a possible alternative to cuts in the international arena, Eberstein is also considering spreading the cuts between national large-scale research activities.

Swedish scientists are campaigning vigorously against withdrawal from CERN. The Swedish Physical Society has been leading a letter-writing campaign to draw attention to the importance to Swedish scientists of continuing membership.

Per Carlson, a professor of particle physics at Stockholm's Royal Institute of Technology, says that membership is of vital importance to Sweden's small particle physics research community. "It would be a scandal to leave CERN at a time when countries like Poland, Hungary and Slovakia are increasing their membership fees to CERN."

On the basis of the recommendations of the Eberstein report, the government is expected to decide in September how to implement the cuts in the 1998 research budget.

Alison Abbott

\section{Body work leads to UK sculptor's arrest}

\author{
IMAGE \\ UNAVAILABLE \\ FOR COPYRIGHT \\ REASONS
}

[LONDON] A British sculptor and a former employee of the Royal College of Surgeons have been arrested and bailed in connection with the removal of the remains of human corpses intended for medical research. The arrests coincided with the discovery by police of parts of the bodies of up to 30 people at houses belonging to Anthony-Noel Kelly (pictured), a sculpture tutor.

An exhibition of Kelly's work earlier this year included a cast of a silver-coated man with parts of his brain cut away.
French law would help scientists to go into business

[PARIS] The French government is planning to introduce legislation that would encourage government-funded scientists to create their own companies and cooperate more with industry. The law will modify the status of researchers as civil servants in order to allow them to work in the private sector.

The proposed law will also allow government scientists to work in a small company for four years while leaving open the possibility of returning to their previous posts. This period would be taken into account in staff evaluations. The researchers would be allowed to own up to 10 per cent of the equity of private companies, and to act as consultants.

Announcing the plans, which have already been approved by the French cabinet, François d'Aubert, France's minister of research, said that scientists were one of the main factors in encouraging economic growth and job creation. "We must give them an opportunity to create companies without any danger to their career, or any conflict of interests," he said.

D'Aubert urged research organizations to create specialized units to support researchers wishing to set up companies. He suggested that scientists starting such ventures should be able to use their laboratories as company premises, provided they paid a "very low rent". He also said that the new rules on equity ownership would bring French practice in line with that in the United States.

The ministry is planning to set up a venture capital fund to support companies created by scientists, in a bid to make up for the relative lack of such funding available in France. But d'Aubert gave no details as to when this fund will be launched, or its size, saying only that it would be funded equally by the public and private sectors.

How successful the initiatives will be in stimulating the creation of companies remains an open question. According to a study by Phillippe Mustar, of the Ecole des Mines de Paris, scientists from the atomic energy commission (CEA) set up fewer companies between 1988 and 1991 than researchers from the national research agency, CNRS, even though they do not suffer from the constraints of being civil servants.

And the demand to set up companies is likely to remain low, in the near future at least. According to one CNRS official, only about ten researchers each year voluntarily ask for information about establishing their own company.

Eric Clover 